\title{
GAYA HIDUP HEDONISME DALAM IKLAN PARIWISATA WONDERFUL INDONESIA “AN EXPLORATION OF THE WONDROUS LABUAN BAJO”
}

\section{HEDONISM LIFESTYLE IN WONDERFUL INDONESIA ADVERTISEMENT "AN EXPLORATION OF THE WONDROUS LABUAN BAJO"}

\author{
Muhamad Sholeh ${ }^{1}$, Gita Juniarti ${ }^{2}$ \\ Email:amad.djokam@gmail.com, gitajuniartimkw@gmail.com \\ ${ }_{1,2}$ Magister Ilmu Komunikasi Universitas Diponegoro \\ Jl. Erlangga Barat VII, Semarang, Indonesia \\ Submitted: 18 Mei 2021| Accepted: 20 Juni 2021 | Published: 30 Juni 2021 \\ Website: https://e-journal.umc.ac.id/index.php/jike/index
}

\begin{abstract}
For young people, vacation has become a primary need. While previously, it was a tertiary need. These changes are related to technological developments, including the creation of the audiovisual platform, Youtube. Wonderful Indonesia also uses Youtube to publish the ad "An Exploration of The Wondrous Labuan Bajo". This study used the semiotic theory of Roland Barthes which examined the cultural changes using four key cultural studies, namely (1) culture and practice of signs, (2) texts and audiences, (3) materialism and non-reductionism, and (4) power. Behind the three-minute ad are connotative signs that reflect hedonism lifestyle. Activities undertaken by young people while on vacation include luxurious cruising on phinisi boats and staying at luxury resorts. Moreover, young people are directed to the use of sophisticated gadgets that enabled them to take selfies and videos anywhere while on vacation. This advertisement shows that the capital owners and people of power are also involved in the lifestyle changes of young people, including hedonism on vacation. Furthermore, this ad does not highlight MSMEs and local traditional culture as the drivers of tourism in Labuan Bajo. The results of this study are criticismsto change the meaning and the lifestyle of vacation activities, and to give an opportunity to develop local MSMEs. These criticisms are addressed to the Indonesian government and the elite groups involved.
\end{abstract}

Keywords: Vacation, hedonism lifestyle, young people, tourism advertisements

\begin{abstract}
ABSTRAK
Bagi anak-anak muda, kegiatan berlibur telah menjadi kebutuhan primer. Sebelumnya, liburan merupakan kebutuhan tersier. Perubahan tersebut berjalan seiring dengan perkembangan teknologi, termasuk terciptanya platform audiovisualYoutube. Wonderful Indonesia juga memanfaatkan Youtube untuk mempublikasikan iklan "An Exploration of The Wondrous Labuan Bajo". Penelitian ini menggunakan teori semiotika Roland Barthes dan mengkaji perubahan budaya tersebut menggunakan empat kata kunci studi kultural, yaitu (1) budaya dan praktik tentang tanda, (2) teks dan khalayak, (3) materialism dan non-reduksionalisme, dan (4) kekuasaan. Di balik iklan berdurasi tiga menit tersebut terdapat tanda-tanda konotatif yang mencerminkan gaya hidup hedonisme. Kegiatan yang dilakukan oleh anak-anak muda ketika berlibur antara lain melakukan pesiar dengan kapal phinisi yang mewah dan menginap di resort berbintang. Selain itu, anak-anak muda juga diarahkan untuk wajib perlengkapan gadget canggih yang dapat melakukan swafoto dan swavideo di mana saja ketika berlibur.Iklan pariwisata ini juga memperlihatkan bahwa pemilik modal dan kekuasaan juga terlibat dalam perubahan gaya hidup anak-anak muda, termasuk hedonisme dalam kegiatan liburan. Selain itu, iklan ini juga tidak menyoroti UMKM dan budaya tradisional setempat sebagai penggerak wisata di Labuan Bajo. Hasil penelitian ini merupakan kritikan tentang perubahan makna dan gaya hidup tentang kegiatan berlibur, serta kesempatan untuk mengembangkan UMKM setempat. Kritikan tersebut ditujukan kepada pemerintah Indonesia dan kelompok elit yang terlibat dalam iklan tersebut.
\end{abstract}

Kata kunci: Liburan,gaya hidup hedonisme, anak-anak muda, iklan pariwisata 


\section{A. PENDAHULUAN}

Youtube menjadi salah satu channel untuk mempromosikan barang dan jasa, termasuk mempromosikan tempat wisata. Kementerian Pariwisata dan Ekonomi Kreatif juga mengoptimalkan upaya mereka dengan memasarkan video promosi wissata Indonesia melalui Youtube. Video tersebut dipublikasikan melalui akun Wonderful Indonesia yang memiliki ratusan ribu pengikut.

Berdasarkan hasil pengamatan penulis di akun YoutubeWonderful Indonesia, tampilan konten yang dipublikasikan di akun YoutubeWonderful Indonesiamengalami perubahan dalam cara penyajiannya iklan dari tahun ke tahun. Pada tahun 2014, Wonderful Indonesia menerbitkan iklan berjudul Visit Indonesia di akun Youtube miliknya. Pada iklan tersebut, terlihat bahwa Wonderful Indonesia menampilkan gambar dari keindahan alam. Hampir semua gambar yang diambil pada iklan tersebut berisi tentang gambar-gambar tentang pemandangan alam di Indonesia. Untuk efek suara, iklan tersebut hanya diiringi musik dan tidak terdengar percakapan dari narator sama sekali. (Youtube Wonderful Indonesia, video Visit Indonesia, diamati pada 18 Juni 2020).
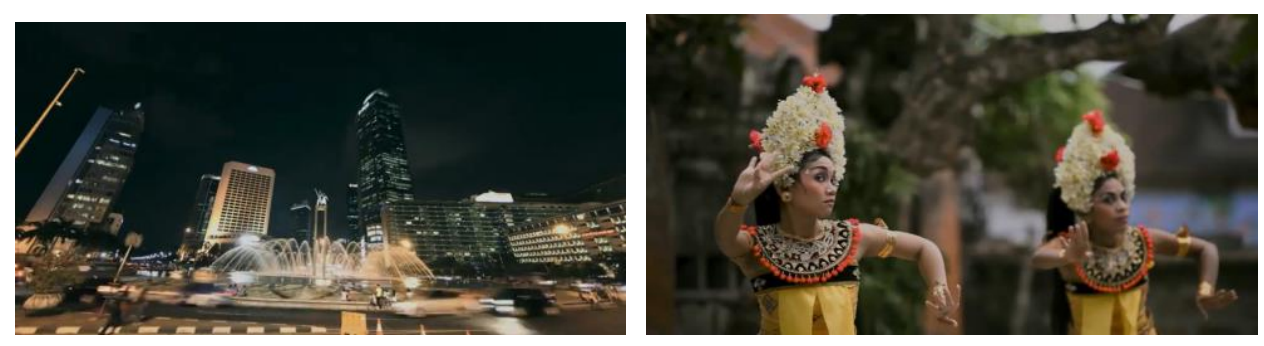

Gambar 1.

Cuplikan scene dari iklan Wonderful Indonesia tahun 2014 (Sumber: YoutubeWonderful Indonesia)

Tahun 2018, Wonderful Indonesia meluncurkan iklan yang berbentuk cerita pendek. Iklan tersebut berjudul The More You Feel, The More You Know. Konten dari iklan berdurasi lima menit itu menggambarkan tentang keluarga turis asing yang berkunjung ke Indonesia. Ketika melihat masyarakat Indonesia, anak-anak dari keluarga tersebut menanyakan tentang perbedaan warna kulit mereka dengan kulit orang Indonesia. Iklan itu menjelaskan bahwa Indonesia memiliki beragam ras dan etnis, sehingga keanekaragaman tersebut menjadi ciri khas dari bangsa Indonesia(Youtube Wonderful Indonesia, video The More You Feel, The More You Know, diamati pada Juni 2020). Penelitian tentang iklan itu telah dianalisis oleh Widiastuti \& Nurtaanzila (2018: 44). Kesimpulan pada penelitian tersebut menjabarkan bahwaiklan Wonderful Indonesia tahun 
2018 menggambarkan lima ikon citra Indonesia, yakni keindahan alam, keunikan budaya, keramahan penduduk, kelezatan makanan, dan kedamaian lingkungan.
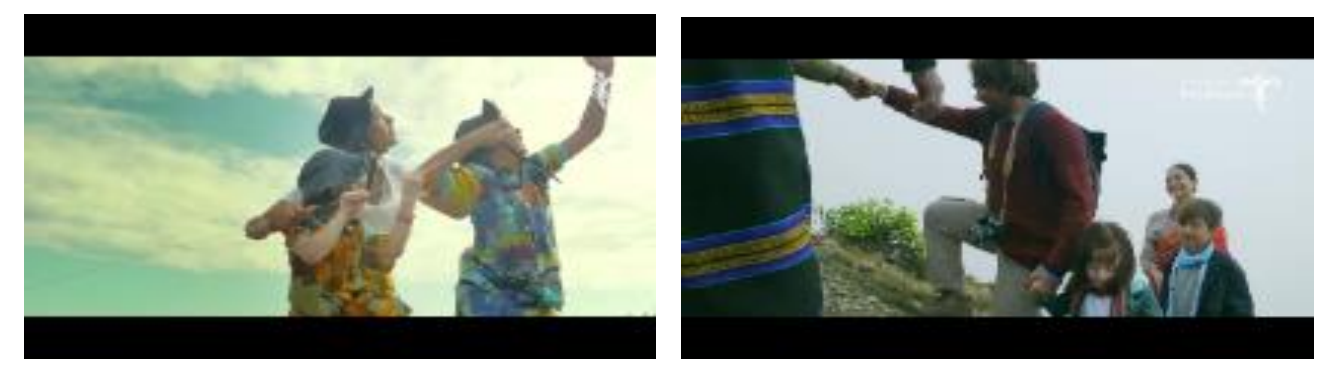

Gambar 2.

Cuplikan scene dari iklan Wonderful Indonesia tahun 2018(Sumber: YoutubeWonderful Indonesia)

Beranjak ke tahun 2020, Wonderful Indonesia meluncurkan iklan yang mengambil scene di Labuan Bajo, Nusa Tenggara Timur (NTT). Perubahan tersebut terlihat di video promosi yang dipublikasi di akun Youtube Wonderful Indonesia. Iklan berdurasi tiga menit itu berjudul An Exploration of The Wondrous Labuan Bajo. Iklan tersebut dibintangi oleh satu pemain, yakni perempuan muda dari ras kulit putih yang menjelajahi Pulau Komodo, Pulau Pandar, Gua Rangko, dan beberapa tempat di Labuan Bajo. Ia menjelajahi tempat-tempat tersebut seorang diri sambil membawa perlengkapan untuk melakukan swafoto dan swavideo. Sesekali, perempuan tersebut bergabung bersama teman-temannya, seperti scene di Ayana Komodo Resort dan scene berlayar di atas kapal (live on board). Perempuan itu membawa gadget canggih yang dapat merekam kegiatannya selama berwisata di Labuan Bajo. (Youtube Wondeful Indonesia, video An Exploration of The Wondrous Labuan Bajo, diamati pada 18 Juni 2020).

Iklan tersebut sejalan dengan perubahan budaya hidup di masyarakat kelas menengah pada saat ini. Dhani (2016), di dalam Tirto.id menuliskan bahwa gaya hidup hedonisme telah mengubah perilaku masyarakat kelas menengah dalam berlibur. Sebelumnya, liburan merupakan kebutuhan tersier, atau bahkan tidak menjadi kebutuhan di dalam kehidupan masyarakat. Namun, kini liburan sudah menjadi kebutuhan sekunder di dalam kehidupan masyarakat kelas menengah. Nurdianisa, dkk (2018: 105) menuliskan bahwa wisatawan yang melakukan perjalanan liburan tersebut memiliki kepuasan sendiri ketika berhasil merekam perjalanan mereka dan memposting hal tersebut di media sosial mereka. Hal tersebut sejalan dengan iklan yang dibuat oleh Wonderful Indonesia, dimana perempuan muda sebagai bintang iklan tersebut menggunakan gadget canggih miliknya untuk mengambil gambar dan merekam banyak hal selama menjelajah Labuan Bajo. 


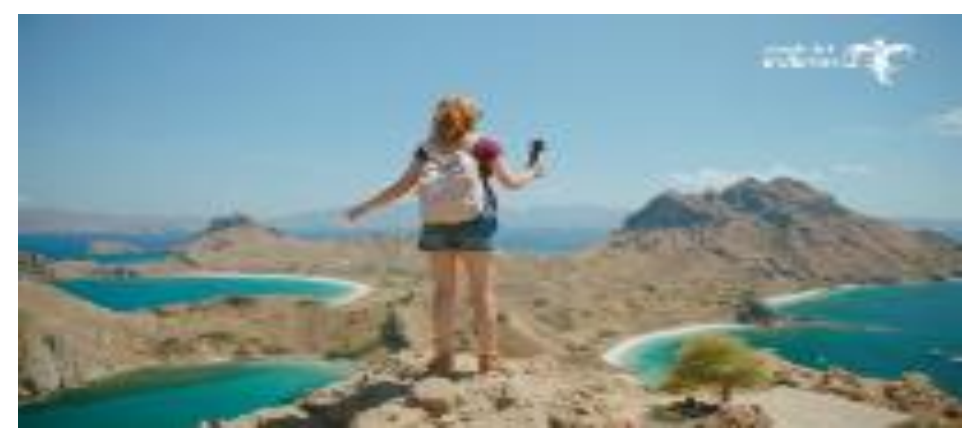

Gambar 3.

Cuplikan scene dari iklan Wonderful Indonesia tahun 2020(Sumber: YoutubeWonderful Indonesia)

Gambar audiovisual memang cukup mempengaruhi perubahan budaya di dalam kehidupan masyarakat. Berto (2017: 8-9) menuliskan bahwa film juga memiliki peranan penting dalam mempopulerkan budaya wisata yang mengarah ke nilai-nilai kapitalisme. Hal itu tergambarkan dari beberapa film tentang budaya wisata, seperti film Haji Backpacker dan Laura \& Marsha. Gambar audiovisual pada setting di film-film tersebut memiliki dampak kapitalisme di balik tayangan film tersebut. Semakin banyak anak-anak muda yang memutuskan untuk melakukan perjalanan ala backpacker ke luar negeri.

Sementara itu, penelitian Hermawan dan Hendrastomo (2018: 13) menyebutkan bahwa halhal yang mempengaruhi generasi muda, khususnya mahasiswa Yogyakarta untuk melakukan liburan secara rutin adalah kebutuhan kegiatan untuk mengisi waktu luang, pengaruh teman, pengaruh media, dan kondisi keuangan atau ekonomi yang cukup. Hal ini membuktikan bahwa liburan telah menjadi gaya hidup mahasiswa Yogyakarta dalam mengisi waktu luang mereka. Liburan juga menjadi upaya mahasiswa untuk membentuk martabatkarena liburan merupakan salah satu cara individu untuk menunjukkan eksistensi diri.

Perkembangan teknologi juga semakin mempermudah anak-anak muda dalam memenuhi kebutuhan liburan mereka. Berdasarkan artikel dari tirto.id, Ulfa (2019) menjabarkan bahwa promo tiket pesawat dan penginapan menjadi incaran para kelas menengah yang menjadikan liburan sebagai kebutuhan mereka. Hal itu dilakukan agar kebutuhan liburan terpenuhi dan eksistensi diri juga terpenuhi. Selain nilai-nilai kapitalisme seperti penganapan dan tiket pesawat, Berto (2017:9) menuliskan bahwa media juga membuat standarisasi untuk para pelancongpelancong muda, seperti gaya busana, tujuan travel, akomodasi, dan transportasi untuk orangorang yang melakukan liburan. Hal ini dimanfaatkan oleh industri-industri kapitalisme untuk memasarkan produk-produk mereka demi keuntungan ekonomi.

Hasil dari penelitian-penelitian di atas menunjukkan bahwa tayangan audiovisual memiliki pengaruh yang besar dalam perubahan budaya di kehidupan masyarakat, khususnya anak-anak muda. Film tentang backpacker dapat menarik perhatian anak-anak muda dan mereka cepat 
terpengaruh untuk melakukan perjalanan backpacker ke luar negeri seperti yang disajikan oleh film itu. Hal serupa juga terjadi ketika anak-anak muda mengonsumsi tayangan tentang liburan di Youtube dan Instagram. Tayangan audiovisual di platform seperti itu memiliki peluang untuk mendorong budaya konsumerisme pada masyarakat.

Salah satu iklan Wonderful Indonesia, “An Exploration of The Wondrous Labuan Bajo” juga menjadi salah satu iklan yang memiliki tujuan mempromosikan wisata melalui platform Youtube. Iklan yang ditayangkan pada platform tersebut merupakan salah satu upaya Wonderful Indonesia untuk menarik minat orang-orang untuk mengunjungi tempat wisata di Indonesia. Berdasarkan hasil penelitian-penelitian di atas (Berto, 2017; Hermawan \& Hendrastomo, 2018), dampak dari tayangan audiovisual yang berkaitan dengan travelling telah mengubah kultur kehidupan anakanak muda pada saat ini. Anak-anak muda memandang bahwa liburan telah menjadi sebuah kebutuhan yang harus dipenuhi. Ketika mereka berlibur, maka terdapat kultur baru lagi di dalam kehidupan mereka terkait eksistensi diri, yaitu mengabadikan setiap kegiatan mereka di tempat liburan dan memposting foto atau video tersebut melalui platform media sosial.

Penelitian ini akan membahas tentang makna-makna dari video berdurasi tiga menit tersebut ketika mempromosikan Labuan Bajo di NTT. Apakah terdapat makna-makna pada tersembunyi di balik iklan tersebut selain mempromosikan wisata di Labuan Bajo? Apakah terdapat ideologi tertentu di balik iklan “An Exploration of The Wondrous Labuan Bajo”? Penelitian ini bertujuan untuk membedah makna-makna dari scene yang diambil oleh tim Wonderful Indonesia pada iklan yang mempromosikan wisata di Labuan Bajo. Iklan tersebut menggunakan bintang iklan seorang perempuan muda dari ras kulit putih dengan style backpacker,dan membawa alat-alat canggih untuk merekam setiap perjalanannya di Labuan Bajo. Penelitian ini bertujuan untuk mengetahui makna-makna di balik setiap scene pada iklan Wonderful Indonesia. Hasil dari penelitian ini dapat menjadi dasar untuk menulis dan melakukan diskusi mengenai kritik yang membangun terkait iklan dan tayangan audiovisual yang berkaitan dengan pariwisata, travelling, dan backpacker.

\section{B. LANDASAN TEORI}

\section{Iklan Pariwisata}

Morissan (2010: 1) menuliskan bahwa periklanan atau promosi merupakan bagian yang tidak terpisahkan dari sistem ekonomi dan sosial di masyarakat modern. Iklan sudah berkembang 
menjadi sistem komunikasi yang sangat penting di kehidupan masyarakat modern. Iklan tidak hanya penting bagi produsen barang dan jasa, tetapi juga penting bagi konsumen. Metode promosi dalam iklan yang dibuat memegang peran penting dalam keberhasilan perusahaan yang menawarkan produk tersebut.

Bidang pariwisata sendiri, Avinda, Sudiarta, dan Karini (2016: 56) menuliskan bahwa promosi merupakan salah satu tahapan dalam pemasaran, dimana tahap ini memiliki peran penting dalam usaha untuk meningkatkan kunjungan wisatawan. Hasil dari promosi wisata dengan tagline "Sunrise of Java" dan "Diamond Tirangle", wisatawan yang berkunjung ke Banyuwangi meningkat signifikan selama lima tahun terakhir. Avinda, Sudiarta, dan Karini (2016: 58) menjabarkan bahwa perkembangan teknologi dan informasi memiliki pengaruh yang besar terhadap kegiatan pemasaran wisata yang dimanfaatkan oleh Dinas Kebudayaan dan Pariwisata Provinsi Jawa Timur dan Kota Banyuwangi. Upaya mereka adalah meluncurkan aplikasi berbasis android dan pemasaran melalui media sosial.

Terkait promosi wisata menggunakan Youtube, Azzahrani (2018: 159) menelaah tentang upaya pemerintah di Indonesia dalam mempromosikan wisata Indonesia menggunakan Youtube Wonderful Indonesia. Hasil penelitian menjabarkan bahwa Youtube selalu berkaitan dengan popularitas video yang dipengaruhi oleh jumlah views, subscribe, like, dan share yang dilakukan oleh akun-akun yang mengunjungi Youtube tersebut. Dari data yang diperoleh, Wonderful Indonesia telah mendapatkan jumlah views, subscribe, like, dan share yang banyak dari lama Youtube. Kementerian Pariwisata dan Ekonomi Kreatif telah mencapai target mereka dalam strategi mempromosikan Indonesia melalui Youtube, meskipun harus terus ditingkatkan.

Pemasaran wisata menggunakan Youtube karena pemasaran menggunakan video memiliki beberapa kelebihan. Fitriyani (2009: 122) menuliskan, media massa memang secara eksplitis menunjukkan tentang ilusi dan ilusi tersebut berpengaruh terhadap kelas menengah ke atas. Fitriyani (2009) mengangkat penelitian tentang mitos kecantikan. Media massa menayangkan video yang menunjukkan mode iklan produk kecantikan yang menunjukkan bahwa cantik itu harus berkulit putih dan berambut lurus. Hal inilah yang membawa kelompok kelas menengah ke atas untuk membeli produk-produk kecantikan yang dapat memutihkan kulit dan meluruskan rambut. Fitriyani (2009) menuliskan bahwa semakin lama media menjadi pembentuk realitas khalayak.

Senada dengan penelitian ini, media promosi pariwisata yang menggunakan Youtube juga dapat menciptakan realitas tentang budaya hedonisme di kalangan masyarakat kelas menengah ke 
atas. Terlebih lagi, dengan menggunakan Youtube, audiens dapat melihat tayangan audio-visual dan audiens dapat melihat tayangan tersebut berulang kali sesuai kehendak audiens.

\section{Teori Semiotika}

Sobur (2009: 15) menuliskan, tanda-tanda adalah perangkat yang digunakan oleh manusia dalam upaya mencari jalan di dunia ini, di tengah-tengah manusia dan bersama-sama manusia. Sementara itu, Morissan (2018: 135) menuliskan bahwa tanda (sign) adalah suatu stimulus yang menandai kehadiran sesuatu yang lain. Morissan (2018) mencontohkan bahwa awan mendung merupakan tanda bahwa hujan akan turun. Semua tanda yang hadir di sekeliling manusia tentunya memiliki makna.

Penelitian ini menggunakan teori semiotika Roland Barthes karena semiotika Roland Barthes tidak hanya menganalisis makna denotatif saja, tetapi juga makna-makna lain yang menunjukkan ideologi dari iklan tersebut. Mudjiyanto \& Nur (2013:77) menjelaskan, gagasan Roland Barthes tentang semiotika ini terdiri dari makna denotasi dan konotasi. Makna denotasi merupakan sebuah kata atau terminologi dari objek. Makna denotasi disebut sebagai 'makna kamus'. Sementara itu, makna konotasi memiliki makna yang subjektif. Singkat kata, denotasi adalah apa yang digambarkan tanda terhadap sebuah objek, sementara konotasi adalah bagaimana cara khalayak menggambarkan objek itu. Berikut peta semiotika Roland Barthes:

\begin{tabular}{|l|l|}
\hline $\begin{array}{l}\text { Signifier } \\
\text { (penanda) }\end{array}$ & $\begin{array}{l}\text { Signified } \\
\text { (petanda) }\end{array}$ \\
\cline { 1 - 1 } $\begin{array}{l}\text { Denotative sign (penanda } \\
\text { denotatif) }\end{array}$ \\
\hline $\begin{array}{l}\text { Connotative signifier } \\
\text { (penanda konotatif) }\end{array}$ & $\begin{array}{l}\text { Connotative } \\
\text { signified } \\
\text { (petanda } \\
\text { konotatif) }\end{array}$ \\
\hline Connotative sign (tanda konotatif) \\
\hline
\end{tabular}

Gambar 4.

Tabel Roland Barthes

\section{Gaya Hidup Hedonisme}

Gaya hidup yang konsumtif atau hedonisme sering terjadi pada remaja atau anak-anak muda. Mangkunegara (2005), di dalam Anggraini \& Santhoso (2017: 132) mengungkapkan bahwa remaja memiliki karakteristik yang masih labil, implusif dalam berbelanja, kurang realistis dalam 
berpikir, dan cenderung berperilaku boros. Hal itulah yang mendorong remaja untuk hidup lebih konsumtif.

Perubahan gaya hidup remaja di Indonesia cukup terlihat, terlebih lagi sejak tumbuhnya media sosial di masyarakat. Prasetyo (2019:692) menjabarkan bahwa penggunaan media sosial memberikan sumbangan terhadap perilaku hedonisme pada anak-anak muda, termasuk mahasiswa di salah satu kampus negeri di Yogyakarta. Hasil peneliian Prasetyo (2019) bisa membuktikan bahwa semakin tinggi intensitas penggunaan media sosial pada anak-anak muda, maka perilaku hedonisme akan semakin tinggi.

Tayangan di Instagram maupun Youtube memang membawa peluang untuk mengubah budaya hidup anak-anak muda untuk menjadi konsumtif atau hedonisme. Tanpa disadari, beberapa hal turut berperan dalam perubahan budaya liburan tersebut. Mulanya, liburan hanya menjadi kebutuhan tersier dan kini kaum kelas menengah. Beberapa penelitian di atas telah membuktikan bahwa anak-anak mud menjadikan liburan sebagai kebutuhan yang harus terpenuhi.

\section{Studi Kultural}

Morissan (2018: 533) menuliskan, studi kultural merupakan perhatian pada bagaimana budaya dipengaruhi oleh berbagai kelompok dominan dan berkuasa. Studi kultural menekankan pada gagasan bahwa media menjaga kelompok yang berkuasa untuk tetap memegang kontrol atas masarakat, sementara mereka yang kurang menguasa hanya bisa menerima apa yang disisakan kepada mereka oleh kelompok berkuasa. Samuel Becker (1984), di dalam Morissan (2018: 583) menjelaskan bahwa tujuan dari studi kultural adalah untuk menyadarkan kembali khalayak dan para pekerja media yang dinilai sudah terlena dengan berbagai ilusi dan rutinitas atau perbuatan yang mereka lakukan agar mereka mengkritisi ilusi tersebut.

Sementara itu, Barker \& Jane (2016: 9-13) menuliskan bahwa studi kultural memiliki beberapa kata kunci. Pada penelitian ini, kata-kata kunci berikut sangat relevan jika dikaitkan dengan objek penelitian berupa iklan pariwisata yang dipublikasikan oleh akun Wonderful Indonesia di Youtube, yakni:

1) Budaya dan praktik tentang tanda. Barker \& Jane (2016) menggambarkan, budaya adalah makna dengan pertanyaan tentang makna sosial bersama dan bagaimana cara manusia dalam memahami dunia. Makna tersebut terbentuk dari praktik nyata, representasi, bahasa, dan kebiasaan masyarakat tertentu. Perubahan budaya tidak berlangsung dengan massif, tetapi perubahan budaya tersebut berlangsung perlahan-lahan. Banyak pihak yang secara 
tidak tampak bergerak untuk mengubah budaya di dalam masyarakat, termasuk budaya hedonisme dalam berlibur.

2) Teks dan khalayak. Teks yang dimaksud oleh Barker \& Jane (2016: 13) ini bukan berupa teks yang berisi kata-kata saja, tetapi juga berisi gambar, suara, objek yang terlihat di dalam video (contoh: baju), dan aktivitas yang dilakukan di dalam video (contoh: sedang berolahraga). Studi kultural meyakini bahwa teks tersebut tidak hanya dibuat untuk mempromosikan sesuatu, tetapi juga mengandung makna-makna tersembunyi di balik video berdurasi tiga menis tersebut. Semakin banyak khalayak yang tertarik untuk mengonsumsi video tersebut, maka khalayak akan menguntungkan pihak produksi.

3) Materialisme dan non-reduksionalisme. Seiring dengan berkembangnya industri modern, diiringi dengan organisasi media yang bergantung pada kapitalisme, maka studi kultural juga menganalisis tentang bagaimana makna dari video yang diproduksi tersebut. Pada kultural studi, makna tersebut bukan hanya dilihat dari tanda-tanda yang muncul di video tersebut, tetapi juga membahas tentang siapa saja yang terlibat di belakang pembuatan video tersebut, siapa pemilik modal, dan pihak mana saja yang terlibat dalam pembuatan video tersebut.

4) Kekuasaan. Di dalam membentuk budaya yang berlaku di dalam masyarakat, masyarakat tidak dapat membentuknya sendiri tanpa adanya pihak yang berkuasa di atasnya.

Pihak yang berkuasa tersebut cenderung berhubungan dengan ras dominan, gender, dan kelas masyarakat yang berlaku di lingkup sosial tersebut.

\section{METODE PENELITIAN}

Penelitian ini menggunakan paradigma konstruktivisme karena menganalisis tentang video yang menceritakan tentang sebuah realitas dan realitas tersebut dibentuk oleh konstruksi sosial. Pendekatan yang digunakan adalah kualitatif dengan analisis semiotika Roland Barthes. Data yang diperoleh dari penelitian ini adalah data primer dan sekunder. Data primer pada penelitian ini adalah scene iklan yang mempromosikan pariwisata berjudul "An Exploration of The Wondrous Labuan Bajo” berdurasi tiga menit. Iklan tersebut diperoleh dari Youtube Wonderful Indonesia.

Data sekunder dari penelitian ini adalah referensi terkait yang berasal dari buku, jurnal, dan artikel lain yang berkaitan dengan permasalahan dari penelitian ini. Selanjutnya, data yang diperoleh dari iklan tersebut akan dianalisis berdasarkan konsep dari teori semiotika Roland Barthes, yakni menganalisis makna-makna yang terkandung di dalam iklan promosi pariwisata itu. 
Setelah mengetahui makna-makna tersebut, penulis berupaya menghubungkannya dengan studi kultural sehingga dapat membaca tentang perubahan budaya liburan yang menjamur di kalangan anak-anak muda. Dengan demikian, penelitian ini dapat melihat upaya kelompok dominan yang secara tak langsung telah mempengaruhi, bahkan mengubah budaya itu.

\section{HASIL DAN PEMBAHASAN}

Iklan ini menceritakan tentang perempuan muda yang melakukan perjalanan seorang diri (solo travelling)ke beberapa tempat di Labuan Bajo. Iklan ini menceritakan dari sudut pandang orang pertama, yakni perempuan muda yang langsung menceritakan tentang Labuan Bajo kepada para penonton. Untuk menganalisis penelitian ini, penulis mengambil beberapa scene yang menjawab pertanyaan penelitian mengenai gaya hidup hedonisme yang tergambarkan dari video berdurasi tiga menit ini. Berikut hasil analisis dari pengamatan pada video tersebut:

A. Analisis semiotika

1) Analisis scene Pulau Padar
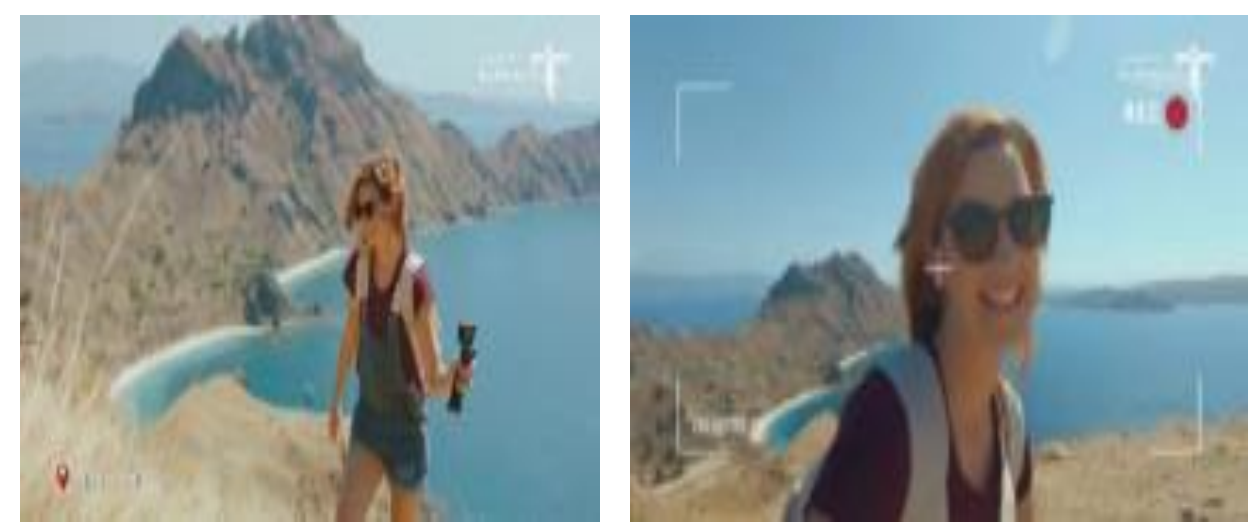

Gambar 5.

Scene Iklan di Pulau Padar

Petanda denotasi dan konotasi pada scene ini adalah style dari perempuan yang mendaki puncak Pulau Pandar ini. Perempuan muda ini berjalan seorang diri ke puncak sambil menggendong ransel (backpack) dan membawa gadget yang dapat mengambil swafoto dan swavideo dimana saja. Perempuan muda tersebut berkata, "Hai, I'm in Padar now". Kemudian, dilanjutkan dengan mengatakan, "Look at this view. It is so beautiful". Ia mengatakan hal tersebut sambil mengarahkan kameranya ke sekelilingnya untuk merekam dirinya dan keseluruhan gambar di Pulau Padar.

Makna denotasi pada scene ini adalah perempuan muda yang sedang berkunjung ke Labuan Bajo. Ia mengenakan pakaian yang santai, yakni celana pendek, kaus, sepatu santai, 
kacamata hitam, dan ransel (backpack) di punggungnya. Ia juga perempuan modern yang membawa gadget yang dapat mengambil foto dan video. Ia datang ke Pulau Padar di Labuan Bajo seorang diri dan mengagumi keindahan Pulau Padar, sehingga ia mengatakan, "Loot at this view. It is so beautiful"'.

Sementara itu, makna komotasi pada scene ini adalah penonjolan terhadap gadget dan cara perempuan muda itu menggunakan gadget tersebut.Ia mengambil swafoto dan swavideo berkali-kali di Pulau Padar. Umumnya, pengambilan swafoto dan swavideo tersebut akan dipublikasikan di media sosial milik perempuan itu untuk meningkatkan eksistensi dirinya. Gadget yang dibawa oleh perempuan muda tersebut sangat identik dengan solo travelling. Hal ini menunjukkan bahwa gadget yang dibawanya sebagai tanda konotasi

\section{2) Analisis scene Taman Nasional Komodo}
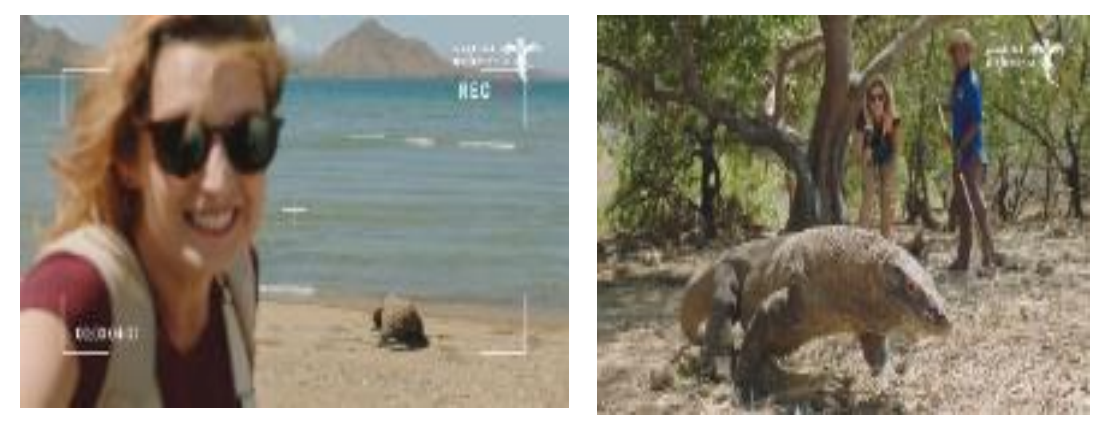

Gambar 6.

Scene Iklan di Taman Nasional Komodo

Petanda pada scene ini adalah budaya merekam setiap perjalannya di Labuan Bajo, termasuk di Taman Nasional Komodo. Perempuan muda ini mengambil gambar komodo di pinggir pantai maupun di hutan menggunakan gadget yang dibawa olehnya. Perempuan itu mengatakan, "Hai, guys. Here we go, at Komodo Natural Park”. Di akhir scene di Taman Nasional Komodo tersebut, perempuan muda ini berkata, "This is the last wild dragon on Earth!".

Makna denotasi dari scene ini adalah rasa senang dan kagum yang terlihat dari wajah bintang iklan tersebut. Ia sangat terpesona dengan hewan endemik dari Indonesia ini. Hal itu ditunjukkan oleh nada suaranya yang benar-benar mengagumi hewan tersebut dan ekspresi bahagianya ketika berfoto dengan komodo. Oleh sebab itu, ia terus mengambil gambar dan video komodo, serta gambar dirinya dengan latar belakang komodo. Gambar dan video tersebut diambil menggunakan gadget yang dibawanya.

Makna konotasi dari scene ini adalah perempuan muda itu berusaha mengambil gambar dan video komodo tersebut, padahal perempuan itu tahu bahwa komodo adalah hewan yang 
sangat berbahaya. Ketika perempuan muda itu merekam gambarnya dengan latar belakang komodo, serta merekam gambar komodo yang sedang berjalan, pawang komodo berdiri di sampingnya untuk mengawasi komodo sambil membawa alat untuk melindungi diri.

Scene ini menunjukkan bahwa individu tidak takut pada komodo sama sekali. Ia mengambil video komodo dari jarak dekat. Hal itu tak jauh berbeda dengan fenomena ketika anak-anak muda sering melakukan kegiatan berbahaya demi mengisi konten di media sosial mereka agar konten tersebut disukai oleh banyak orang. Hal tersebut menunjukkan tanda konotatif pada scene ini adalah memiliki gadget untuk mengambil swafoto dan swavideo ketika berlibur. Ketika mengambil gambar dan video, anak-anak muda harus memiliki rasa berani, terlebih lagi jika pengambilan gambar tersebut berpotensi membahayakan individu.

\section{3) Analisis scene di Kapal Phinisi}

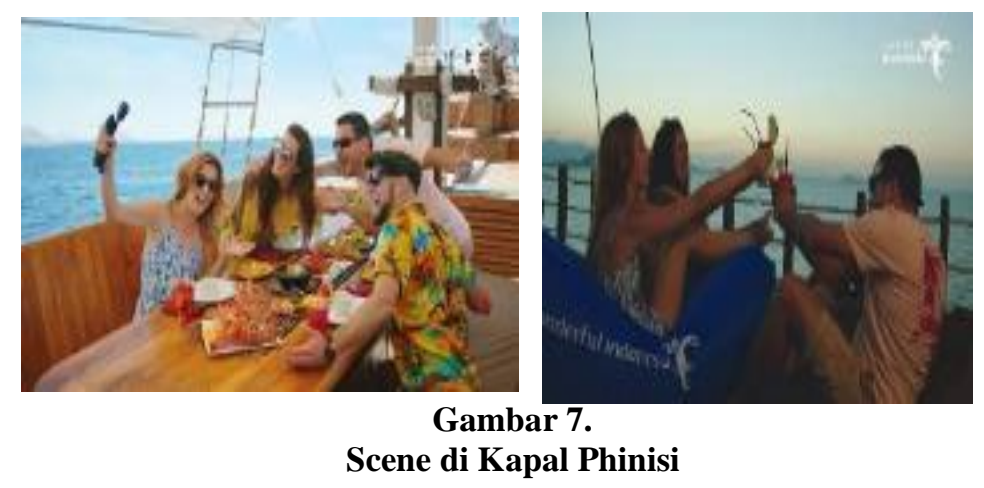

Petanda pada scene ini adalah kegiatan yang dapat dilakukan oleh orang-orang ketika berlibur dengan menyewa kapal phinisi di Labuan Bajo. Scene ini menunjukkan perempuan muda yang mengarahkan kamera ke wajahnya dan teman-temannya, lalu mengatakan, "Hai, everyone. I'm in phinisi boatnow". Scene tersebut diisi dengan aktivitas makan siang bersama di atas kapal phinisi. Setelah scene makan siang bersama, mereka juga menikmati minuman sambil duduk di kursi santai dan melihat matahari senja.

Makna denotasi dari scene ini adalah perempuan muda tersebut dapat merasakan kebahagiaan bersama teman-temannya ketika menghabiskan waktu liburan di atas kapal phinisi. Hal itu terlihat dari tawa lebar yang mengisi wajah-wajah pemain pada scene ini.

Makna konotasi, scene ini menggambarkan bahwa kebahagiaan tersebut diciptakan dari liburan yang mewah di atas kapal. Kapal phinisi bukan kapal yang dapat disewa oleh setiap orang yang berwisata ke Labuan Bajo, karena untuk menyewa kapal phinisi membutuhkan dana yang sangat banyak. Oleh sebab itu, tanda konotasi yang digambarkan dari scene ini adalah kegiatan yang dapat dilakukan oleh orang-orang di atas kapal phinisi ketika berlibur. 
Jika anak-anak muda ingin merasakan liburan yang bahagia, maka mereka harus menghabiskan waktu mereka di atas kapal phinisi bersama teman-teman mereka.

\section{4) Analisis scene di Ayana Komodo Resort}
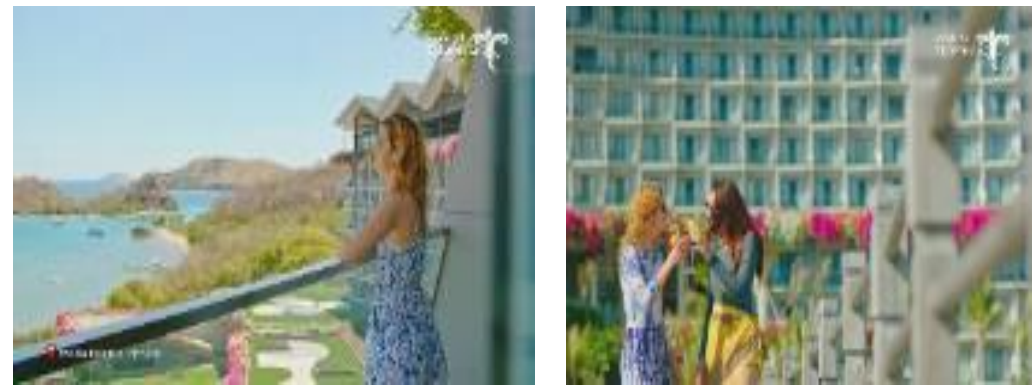

Gambar 8.

Scene di Ayana Komodo Resort

Petanda dari scene ini adalah salah satu hotel yang sangat terkenal di Labuan Bajo, yaitu Ayana Komodo Resort. Scene tersebut dimulai dengan perempuan muda yang keluar dari kamar hotel dan menikmati pemandangan Labuan Bajo dari beranda hotelnya. Ia mengatakan, "I'm enjoying this beautiful morning”. Scene tersebut dilanjutkan dengan gambar dua perempuan muda yang sedang menikmati minuman di pinggir kolam renang. Perempuan muda iu berkata, "I'm in Ayana Komodo Resort. It's beautiful".

Makna denotatif dari scene di Ayana Komodo Resort ini adalah perempuan muda itu terlihat menikmati liburannya di hotel tersebut. Ia dapat menikmati pemandangan laut dari ketinggian dan menikmati pelayanan di hotel tersebut bersama temannya. Tampak ekspresi bahagia menghiasi wajah kedua pemain di dalam scene ini.

Makna konotatif dari scene ini adalah liburan yang ideal dan membuat turis muda merasa bahagia adalah liburan di hotel yang ditampilkan pada gambar di atas. Artinya, jika masyarakat di Indonesia ingin bahagia seperti perempuan muda tersebut, maka mereka harus berlibur ke lokasi tersebut, termasuk ke Ayana Komodo Resort. Penanda konotatif yang tercermin dari scene ini adalah bentuk kemewahan yang sangat terlihat dari hotel tersebut.

\section{5) Analisis scene di Gua Rangko}



\section{Gambar 9. \\ Scene di Pulai Rangko}

Petanda dari scene ini adalah individu yang turun dari kapal dan menjelajahi Gua Rangko, salah satu tempat wisata di Labuan Bajo sambil memegang gadget miliknya untuk mengambil swafoto dan swavideo. Scene tersebut dimulai dengan individu yang turun dari atas kapal dan mengambil gambar tulisan yang diatas ukiran kayu "Welcome to Gua Rangko". Individu berjalan kaki menuju ke Gua Rangko. Ua melewati hutan sebelum tiba di Gua Rangko. Setelah menjejakkan kaki di Gua Rangko, perempuan muda itu berenang di danau yang berada di dalam gua itu. Ia mengambil swavideo sambil berenang dan mengatakan, “I'm in Gua Rangko. It's beautiful. This cave is gorgeous".

Makna denotatif dari scene ini adalah perempuan muda tersebut turun dari kapal dan mengambil video di sekitarnya dengan menggunakan gadget yang dibawanya. Ia menjelajahi hutan untuk menuju ke Gua Rangko yang menjadi salah satu wisata di Labuan Bajo. Di dalam Gua Rangko, terdapat sebuah danau. Perempuan itu berenang di dalam danau tersebut sambil memegang gadget untuk mengambil swavideo. Ia tersenyum bahagia ketika menjelajahi dan berenang di dalam Gua Rangko. Artinya, pemandangan di dalam Gua Rangko sangat indah sehingga perempuan muda itu terkesan.

Sementara itu, makna konotatif dari scene di Gua Rangko ini adalah ekspresi gembira dari perempuan muda itu ketika merekam banyak hal sejak turun dari kapal hingga berenang di dalam Gua Rangko. Hal tersebut menunjukkan bahwa perempuan muda tersebut telah melakukan sesuatu yang membuatnya bahagia, seperti berenang di danau Gua Rangko sambil memegang kamera, dan kebahagiaan tersebut berusaha diabadikan oleh perempuan muda tersebut melalui swavideo. Kegiatan perempuan muda yang berwisata seorang diri (solo travelling) dan tidak bisa terlepas dari gadget di tangannya itu juga menjadi tanda konotatif dari video promosi pariwisata ini.

\section{Gaya Hidup Hedonisme di Dalam Iklan Promosi Wisata}

Terkait gaya hidup hedonisme, Trimartati (2014: 22) menuliskan bahwa gaya hidup berkaitan erat dengan perkembangan zaman dan perkembangan teknologi. Hasil dari penelitian Trimartati (2014: 27), mahasiswa di Yogyakarta menganggap bahwa gaya hidup hedonisme akan memberikan kesenangan dan kenikmatan, sehingga kesenangan tersebut merupakan tujuan utama di dalam hidup seseorang. 
Hal tersebut dapat dikaitkan dengan hasil dari analisis semiotika yang dijabarkan di atas. Berdasarkan hasil analisis di atas, tanda-tanda konotatif yang diperlihatkan pada video berdurasi tiga menit itu cukup beragam. Pertama, gadget yang dipegang oleh perempuan muda di dalam video tersebut. Ketika memiliki gadget tersebut, perempuan muda itu dapat melakukan swafoto dan swavideo ketika menjelajahi Labuan Bajo.

Tanda konotatif lainnya adalah keberanian perempuan muda itu dalam mengambil gambar dan video, seperti pengambilan gambar komodo dan ketika berenang di Gua Rangko. Meskipun banyak resiko yang harus ditemui oleh perempuan itu ketika mengambil swavideo di dekat komodo dan di dalam Gua Rangko, namun ia tetap melakukannya. Ketiga, tanda konotatif lain adalah ekspresi bahagia perempuan muda tersebut ketika menghabiskan masa-masa liburannya di tempat yang mewah, seperti kapal phinisi dan Ayana Komodo Resort.

Tanda-tanda konotatif tersebut menunjukkan bahwa Wonderful Indonesia juga berperan dalam mencerminkan bahwa liburan dengan kemewahan dan liburan dengan berbagai macam tantangan sekaligus resiko dapat mendatangkan kebahagiaan di kalangan anak-anak muda. Sesuai dengan kutipan Barker \& Jane (2016) bahwa budaya terbentuk dari makna yang diperoleh dari praktik nyata, representasi, bahasa, dan kebiasaan masyarakat tertentu. Berdasarkan analisis makna semiotika Roland Barthes di atas, penulis dapat melihat bahwa iklan ini mengikuti budaya liburan anak-anak muda di Indonesia, seperti membawa gadget untuk merekam kegiatan mereka di lapangan dan mempublikasikan kegiatan tersebut di media sosial.

Pada iklan tersebut, Wonderful Indonesia mengulang kegiatan perempuan muda ketika melakukan swafoto dan swavideo di berbagai tempat di Labuan Bajo. Swavideo tersebut diambil dari scene pertama ketika mendaki puncak Pulau Padar, scene di Taman Nasional Komodo, scene di Gua Rangko, dan juga scene ketika perempuan muda itu makan siang di kapal phinisi bersama teman-temannya. Hal itu menunjukkan bahwa budaya liburan anak-anak muda sangat identik dengan swafoto dan swavideo. Sesuai dengan kalimat yang dituliskan oleh Trimartati (2014: 22), yaitu gaya hidup berubah sesuai dengan perkembangan teknologi. Anak-anak muda tertantang untuk melakukan kegiatan yang beresiko ketika liburan sambil membawa gadget untuk melakukan swafoto dan swavideo, kemudian hasil dari pengambilan gambar dan video tersebut dapat dipublikasikan di media sosial.

Sementara itu, tanda konotatif lain yang menunjukkan budaya hedonisme adalah scene di kapal phinisi dan Ayana Komodo Resort. Hal ini berhubungan dengan kata kunci teks dan khalayak seperti yang dijabarkan oleh Barker \& Jane (2016) mengenai studi kultural, dimana teks tidak hanya mempromosikan dan memperkenalkan tentang sesuatu, tetapi teks tersebut juga 
memiliki makna-makna lain yang juga mendorong terhadap perubahan budaya. Pada penelitian ini, budaya liburan anak-anak muda diasumsikan mulai berubah. Ulfa (2019) di dalam Tirto.id menjabarkan bahwa liburan mulanya hanya kebutuhan tersier. Rekreasi akan diadakan jika individu merasa penat dan butuh berkunjung ke tempat-tempat yang baru.

Iklan Wonderful Indonesia ini tidak hanya mengajak individu untuk melihat alam dari Labuan Bajo yang sangat indah, tetapi juga kemewahan yang dapat dinikmati oleh anak-anak muda ketika berkunjung ke Labuan Bajo, yakni kemewahan di kapal phinisi dan penginapan Ayana Komodo Resort. Hal itu dapat dilihat dari scene di dua tempat tersebut. Scene itu menunjukkan bahwa anakanak muda juga menghabiskan waktu untuk berlibur dengan gaya hidup yang hedonisme. Anakanak muda merasa bahagia ketika mereka berkumpul di kapal phinisi dan menghabiskan liburan di Ayana Komodo Resort, sehingga scene tersebut menggambarkan bahwa liburan yang ideal untuk anak-anak muda yang ingin eksis, terlihat berbeda, dan mendatangkan kebahagiaan adalah liburan dengan gaya hidup hedonisme seperti yang terlihat di iklan tersebut.

\section{PEMBAHASAN DISKUSI}

Pembahasan pada penelitian ini memang berkaitan dengan teks dan perubahan budaya yang dilihat dari tanda-tanda konotatif hasil analisis semiotika Roland Barthes. Pembahasan mengenai studi kultural tidak hanya terletak pada perubahaan budaya dan makna-makna di dalam teks saja. Sesuai dengan apa yang disampaikan oleh Barker \& Jane (2016), materialisme dan kekuasaan juga menjadi hal yang mempengaruhi perubahan budaya di dalam kehidupan sehari-hari, termasuk perubahan budaya liburan dengan gaya hidup hedonisme di kalangan anak-anak muda.

Wonderful Indonesia merupakan produk yang dibuat oleh Kementerian Pariwisata dan Ekonomi Kreatif. Hal yang terjadi adalah pada iklan berdurasi tiga menit tersebut, Wonderful Indonesiatidak menonjolkan video berupa budaya lokal yang berkaitan dengan Labuan Bajo atau Nusa Tenggara Timur. Terdapat scene yang terletak di paling akhir tentang Tarian Caci yang dapat dinikmati oleh turis yang berwisata di Labuan Bajo.

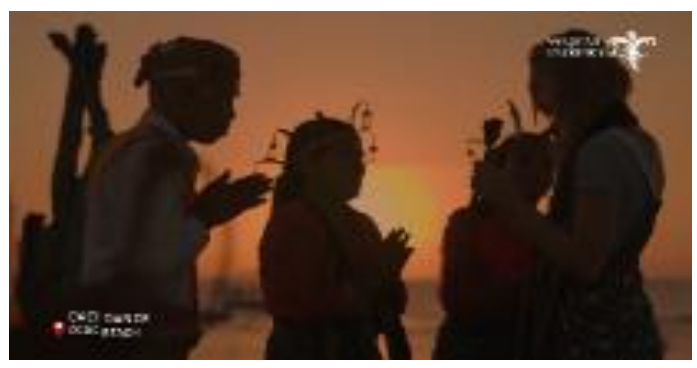

Gambar 10.

Cuplikan scene dari Tarian Caci yang berada di akhir tayangan iklan (Sumber : YoutubeWonderful Indonesia) 
Jika dibandingkan dengan sejumlah scene lain yang diambil pada iklan pariwisata ini, halhal yang ditonjolkan adalah keindahan alam dan kemewahan. Hal ini butuh dianalisis lebih lanjut terkait dengan kata kunci lain yang terdapat pada studi kultural, yakni materialisme dan kekuasaan. Kata kunci tersebut berupaya menguak peran dari pihak-pihak yang berdiri di balik pembuatan video, salah satunya pihak yang memberi modal untuk iklan tersebut.

Labuan Bajo tidak hanya memiliki penginapan berupa Ayana Komodo Resort saja, tetapi juga penginapan yang digagas oleh masyarakat-masyarakat kelas menengah ke bawah. Masyarakat dari kelas menengah ke bawah membangun Usaha Mikro, Kecil, dan Menengah (UMKM), namun mereka tidak memiliki media yang besar untuk mempromosikan produk-produk mereka. Pada iklan yang memperkenalkan tentang Labuan Bajo tersebut, Wonderful Indonesia condong memperkenalkan tentang Ayana Komodo Resort yang dimiliki oleh pemilik modal besar. Ayana tidak hanya membangun hotel di Labuan Bajo saja, tetapi juga di Bali, Jakarta, dan Karawang. Selain cuplikan scene dari group properti Ayana, group yang bertanggungjawab terhadap kapalkapal phinisimewah yang dilengkapi dengan bar dan koki di atas kapal juga mendapat 'porsi' untuk ditampilkan di dalam iklan pariwisata Wonderful Indonesia.

Hal ini sesuai dengan studi kultural yang digagas oleh Stuart Hall, bahwa orang-orang yang memiliki modal besar atau berasal dari kelas elit memegang kuasa yang besar dan dapat mengubah budaya serta cara berpikir dari anak-anak muda, termasuk budaya liburan dengan gaya hidup hedonisme.

Selain itu, pada studi kultural, tertulis bahwa makna-makna yang terkandung di dalam teks tidak hanya berisi makna kata saja, tetapi juga mengandung makna lain yang lebih jauh lagi. Seperti halnya video berdurasi tiga menit yang dipublikasikan oleh akun Wonderful Indonesia, video itu tidak hanya membahas tentang arti denotatif saja, tetapi juga makna lain yang menggambarkan tentang tujuan lain di balik promosi wisata Labuan Bajo ini. Iklan promosi wisata ini tidak hanya membahas tentang keindahan alam di Labuan Bajo, tapi iklan ini juga menumbuhkan gaya hidup hedonisme di kalangan anak-anak muda. Lebih jauh lagi, iklan ini juga memperkenalkan sarana-sarana yang disediakan oleh para pemilik modal, sehingga anak-anak muda memiliki keinginan untuk berlibur seperti bintang iklan Wonderful Indonesia pada iklan ini, yakni berlibur di resort berbintang dan di kapal phinisi yang mewah.

\section{E. SIMPULAN}

Berdasarkan analisis semiotika Roland Barthes pada iklan Wonderful Indonesia berdurasi tiga menit ini, terdapat beberapa tanda konotatif yang mencerminkan budaya liburan anak-anak muda. Hal itu tergambarkan pada bintang iklan yang dipilih, yakni perempuan muda yang 
melakukan perjalanan seorang diri (solo travelling) di sejumlah tempat di Labuan Bajo. Busana yang dikenakan pun menunjukkan style anak muda, yakni ransel (backpack), sepatu kets, topi, celana pendek, dan kaus santai. Iklan ini juga mencerminkan perilaku hedonisme. Hal itu terlihat dari gadget yang dipegang oleh perempuan muda yang tampil di video tersebut. Ia terus merekam seluruh kegiatannya di Labuan Bajo, mulai dari Pulau Padar hingga Gua Rangko. Perilaku hedonisme juga terekam dalam scene anak-anak muda yang menghabiskan waktu di kapal phinisi, dan menghabiskan waktu liburan di Ayana Komodo Resort.

Hasil dari pembahasan dan diskusi menyimpulkan bahwa iklan Wonderful Indonesia memiliki peran dalam perubahan kebiasaan pada kegiatan travelling, sehingga menyebabkan perubahan budaya. Hal tersebut dipengaruhi oleh pihak-pihak kapitalis yang memiliki materi dan kekuasaan. Hal ini menunjukkan bahwa pemilik materi dan kekuasaan mampu mengubah kebiasaan dan gaya hidup masyarkat melalui peran iklan dan teknologi.

\section{DAFTAR PUSTAKA}

Anggraini, Randi Tri dan Santhoso, Fauzan Heru. 2017. Hubungan Antara Gaya Hidup Hedonis dengan Perilaku Konsumtif pada Remaja. Gadjah Mada Journal of Psychology Vol. 3. No. 3.

Avinda, Chyntiya Betari, dkk. 2016. Strategi Promosi Banyuwangi Sebagai Destinasi Wisata (Studi Kasus pada Dinas Kebudayaan dan Pariwisata). Jurnal IPTA Vol. 4 No. 1.

Azzahrani, Mardhiyah. 2018. Strategi Komunikasi Pemasaran Kementerian Pariwisata Indonesia dalam Pesona Indonesia Melalui Youtube. Jurnal Manajemen Komunikasi Vol. 2. No. 2

Barker, Chris dan Jane, Emma. 2016. Cultural Studies Theories and Practice $5^{\text {th }}$ Edition. London : SAGE Publication Ltd.

Berto, Agustinus Rusdianto. 2018. The Capitalization of Backpacking Tourism Culture in Indonesia Films. Jurnal Komunikasi ISI Vol. 3 No. 1.

Dhani, Arman. 2016.Liburan Wajib Ala Kelas Menengah. https://tirto.id/liburan-wajib-ala-kelasmenengah-dx

Fitriyani, Inda. 2009. Iklan dan Budaya Popular: Pembentukan Identitas Ideologis Kecantikan Perempuan oleh Iklan di Televisi. Jurnal Ilmu Komuniasi Vol. 6. No. 2.

Hermawan, Heru dan Hendrastomo, Grendi. 2017. Traveling Sebagai Gaya Hidup Mahasiswa Yogyakarta. Jurnal Societas Pendidikan Sosiologi Vol 6. No.

Morissan. 2018. Teori Komunikasi Individu Hingga Massa Cetakan ke-4. Jakarta: Prenada Media Group.

----------. 2010. Periklanan Komunikasi Pemasaran Terpadu. Jakarta: Penerbit Kencana.

Mudjiyanto, Bambang dan Nur, Emilsyah. 2013. Semiotika dalam Metode Penelitian Komunikasi (Semiotics In Research Method of Communication). Jurnal Penelitian Komunikasi, Informatika dan Media Massa. Vol. 16, No. 1.

Nurdianisa, Lucky, dkk. 2018. Analisis Motivasi Wisatawan dalam Berbagi Pengalaman Wisata Melalui Media Sosial Instagram. Journal of Indonesian Tourism, Hospitality, and Recreation. Vol. 1, No. 1.

Parmentier, Richard. J. 2016. Signs and Society: Further Studies in Semiotic Antrophology. Bloomington, Indiana: Indiana University Press. 
Prasetyo, Handy Yoga. 2019. Hubungan Intensitas Penggunaan Instagram dengan Perilaku Hedonisme pada Mahasiswa Bimbingan dan Konseling. Jurnal Riset Mahasiswa Bimbingan dan Konseling. Vol. 5, No. 9.

Trimartati, Novita. 2014. Studi Kasus tentang Gaya Hidup Hedonisme Mahasiswa Bimbingan dan Konseling Universitas Ahmad Dahlan. Jurnal Psikopedagogia. Vol. 3, No.1.

Ulfa, Maria. 2019.Tren Traveling 2019, dari Pergi Sendiri hingga Hilangnya Selfie. https://tirto.id/tren-traveling-2019-dari-pergi-sendiri-hingga-hilangnya-selfie-ddxx

Widiastuti, Rina dan Nustaanzila, Lastria. 2018. Membaca Citra Indonesia dalam Arsip Audio Visual Kementerian Pariwisata. Jurnal Diplomatika. Vol. 2, No. 1.

YoutubeWonderful Indonesia. An Exploration of The Wondrous Labuan Bajo.https://www.Youtube.com/watch?v=PUY26b2JfQY\&t=41s 